\title{
9 - 10 KLASIŲ MOKINIŲ DALYVAVIMAS MOKYKLOJE VYKDOMAME SVEIKATOS STIPRINIMO PROCESE
}

\author{
Rūta Maceinaitė, Genẻ Šurkienė, Rita Sketerskienė, Žymantas Žandaras \\ Vilniaus universiteto Medicinos fakulteto Sveikatos mokslu institutas
}

Raktažodžiai: mokinių sveikatos stiprinimas, dalyvavimas sveikatos stiprinimo procese, sveikatos stiprinimas mokykloje.

\section{Santrauka}

Mokykla laikoma tinkamiausia vieta paauglių sveikatos stiprinimo procesui. Pagrindinis sveikatos stiprinimo proceso komponentas yra dalyvavimas jame, todèl norint, kad sveikatos stiprinimo procesas būtų efektyvus, būtina ị jị ịtraukti kuo daugiau mokinių. Tyrimo tikslas - įvertinti 9 - 10 klasių mokinių dalyvavimą mokykloje vykdomame jų sveikatos stiprinimo procese. Tyrimo metu apklausti 3574 devintujų ir dešimtujų klasių mokiniai iš 110 ịvairių Lietuvos mokyklų. Paplitimo ìverčiams apskaičiuoti 95 proc. PI, ranginių duomenų analizei panaudoti Mann Whitney ir Kruskal Wallis testai. Nustatant veiksnius, turinčius ịtakos mokinių norui aktyviau dalyvauti mokykloje vykdomame jų sveikatos stiprinimo procese, sudaryti logistinès regresijos modeliai, gauti pakoreguoti šansų santykiai, apskaičiuoti jų 95 proc. PI. Aktyviai arba labai aktyviai mokinių sveikatos stiprinimo procese dalyvavo 10,1 proc. mokinių. Jų aktyvumas buvo reikšmingai susijęs su lytimi, amžiumi, gyvenamaja vieta, mokymosi mokykloje trukme, pastarojo pusmečio pažymių vidurkiu, mokyklos tipu, jos vieta bei ugdymo įstaigos priklausymu (nepriklausymu) SSM tinklui. Per pastaruosius metus 41,9 proc. mokinių dalyvavo renginiuose bei 21,8 proc. mokinių padèjo renginius organizuoti. Beveik 70 proc. mokinių norejjo arba bent iš dalies norejjo aktyviau dalyvauti mokykloje vykdomame jų sveikatos stiprinimo procese, šis noras buvo reikšmingai susijęs su mokinių lytimi. Daugumos mokinių dalyvavimo sveikatos stiprinimo procese lūkesčiai buvo pozityvūs: 53,1 proc. respondentų manè, kad jie igis sveikatos stiprinimui reikalingų žinių, 41,0 proc. mokinių teigè, kad jie taps fiziškai aktyvesni. Didžiausiai daliai mokinių aktyviau dalyvauti sveikatos stiprinimo procese trukdè jų laiko, noro ir žinių stoka (atitinkamai 60,8 proc., 52,5 proc. ir 24,3 proc.).

\section{Ivadas}

Paauglysteje, kurią Pasaulio sveikatos organizacija apibrezžia kaip amžiaus tarpsnị nuo 10 iki 19 metų, susiformavusius gyvensenos ịpročius vèliau pakeisti yra labai sunku, todèl šiuo unikaliu žmogaus raidos laikotarpiu būtina imtis priemonių, padedančių suformuoti paauglių sveikatai palankius gyvensenos ípročius ir tvirtus ateities sveikatos pagrindus [1]. Viena iš tokių priemonių - sveikatos stiprinimo procesas.

Otavos chartijoje, pagrindiniame sveikatos stiprinimo dokumente, pabrèžiama, kad žmonès sveikatą stiprina ir palaiko savo kasdienio gyvenimo aplinkoje, kurioje jie mokosi, dirba, linksminasi ir myli [2]. Viena iš paauglių kasdienio gyvenimo aplinkos dalių yra mokykla, kuri neretai laikoma tinkamiausia vieta sveikatos stiprinimo procesui. Mokykloje paaugliai praleidžia daugiau nei trečdalị savo laiko, didžiajai daliai mokinių mokykla yra socialinio gyvenimo centras [3].

Sveikatos stiprinimo procesas mokykloje gali būti apibrèžiamas kaip bet kokia veikla, kuria siekiama pagerinti ir (ar) apsaugoti visos mokyklos bendruomenès narių (mokytojų, mokinių, jų tėvų (globejjų, rūpintojų) ir kitų mokyklos darbuotojų) sveikatą $[4,5]$. Pagrindinis sveikatos stiprinimo proceso komponentas yra dalyvavimas jame [6]. Mokslinių tyrimų rezultatai rodo, kad mokykloje vykdomame sveikatos stiprinimo procese dalyvaujantys mokiniai jaučia didesnę motyvaciją, labiau pasitiki savimi, igyja daugiau ịūdžių, žinių bei kompetencijų, geriau vertina savo sveikatą, pagerẻja jų sveikatos raštingumas, gyvensenos ịpročiai, o kartu ir sveikata $[7,8]$.

Mokinių dalyvavimas yra nepaprastai svarbus sveikatos stiprinimo efektyvumui, todèl nekyla abejonių, kad tik tada, kai bus užtikrintas visų mokinių dalyvavimas, bus galima tikètis geriausių sveikatos stiprinimo rezultatų $[6,9,10]$. Tiek Lietuvoje, tiek užsienyje atlikta labai nedaug tyrimų, kurių metu būtų nagrinejjamas mokinių dalyvavimas mokykloje vykdomame jų sveikatos stiprinimo procese. Tokių tyrimų stoka lèmé tyrimo tikslą.

Tyrimo tikslas - įvertinti 9 - 10 klasių mokinių dalyvavimą mokykloje vykdomame jų sveikatos stiprinimo procese. 


\section{Tyrimo medžiaga ir metodai}

Momentinis tyrimas atliktas anoniminès anketinès apklausos būdu. Originali anketa parengta naudojantis Sveikatą stiprinančių mokyklų (toliau - SSM) veiklos vertinimo vadove, parengtame Valstybinio aplinkos sveikatos centro, pateiktais klausimais [11]. Atsižvelgiant i bandomojo tyrimo rezultatus, anketa buvo pakoreguota. Galutineje anketoje buvo pateikti 46 klausimai, apimantys 5 klausimų grupes. Vienos iš 5 grupių klausimais buvo siekiama įvertinti pagrindinius mokinių dalyvavimo sveikatos stiprinimo procese aspektus.

SSM bei šiam tinklui nepriklausančios gimnazijos ir pagrindinès mokyklos buvo suskirstytos ị didžiujų miestų, miestų, miestelių, kaimų mokyklas. Panaudojus sluoksninès imties sudarymo metodą, iš kiekvienos mokyklu grupès, pasinaudojus atsitiktinių skaičių generatoriumi, paprastos atsitiktinès atrankos būdu buvo atrinktas kiekvienos mokyklų grupès dydžiui proporcingas mokyklų skaičius. Mokyklos direktoriams atsisakius dalyvauti tyrime, atsitiktinai buvo įtrauktos kitos, tai pačiai grupei priklausančios mokyklos. Tyrime dalyvavo 110 Lietuvos mokyklų 9-10 klasių mokiniai. Šių klasių mokiniai pasirinkti neatsitiktinai. Dažniausiai šiose klasėse mokosi 15-16 metų paaugliai, kurie priklauso viduriniajai (tarpinès) paauglystès stadijai. Šios stadijos paaugliams, skirtingai nei kitų stadijų, būdingi mąstymo, psichosocialinès brandos ypatumai $[12,13]$. Be to, šioje stadijoje formuojasi gyvensenos igūdžiai bei labai padidèja rizikingos elgsenos tikimybè, todèl šiuo laikotarpiu taikant tinkamas visuomenès sveikatos intervencijas, tokias kaip mokinių sveikatos stiprinimas, galima pagerinti tiek paauglių, tiek jau suaugusių žmonių sveikatą [14].

Mokinių apklausa buvo vykdoma nuo 2018 metų gegužès iki 2019 metų balandžio mėnesio. Buvo išdalinta 4495 anketų, iš kurių 3360 grąžintos užpildytos (atsako dažnis - 74,7 proc.). Analizei panaudotos 3574 teisingai užpildytos mokinių anketos. Tyrimui atlikti gautas Vilniaus regioninio biomedicininių tyrimų etikos komiteto leidimas ( $2017 \mathrm{~m}$. spalio $3 \mathrm{~d}$. leidimas atlikti biomedicininį tyrimą Nr. 158200-17-953-458), Švietimo ir mokslo ministerijos (dabar - Švietimo, mokslo ir sporto ministerija) bei Sveikatos apsaugos ministerijos pritarimas.
Mokinių anketinès apklausos duomenų statistiniam apdorojimui naudotos Stata bei WinPepi statistinès programos. Paplitimo įverčiams buvo apskaičiuoti 95 proc. PI. Norint mokinius suskirstyti pagal jų aktyvumą dalyvaujant mokykloje vykdomame jų sveikatos stiprinimo procese, kiekvienam apklaustajam pagal jo dalyvavimą kiekvienoje sveikatos stiprinimo veikloje buvo skirti balai (jei asmuo per pastaruosius metus dalyvavo konkrečioje veikloje, jam skiriami 2 balai, jei dalyvavo daugiau nei prieš metus -1 balas, jei sveikatos stiprinimo veikloje niekada nedalyvavo - balų neskiriama). Respondentai pagal jų turimų balų sumas buvo suskirstyti ị nedalyvaujančius sveikatos stiprinimo procese, pasyvius dalyvius, vidutiniškai aktyvius, aktyvius dalyvius bei labai aktyvius dalyvius. Mokinių aktyvumo dalyvaujant mokykloje vykdomame jų sveikatos stiprinimo procese skirstinių analizei panaudoti Mann Whitney ir Kruskal Wallis testai. Siekiant išsiaiškinti, kokie veiksniai turi reikšmingos įtakos mokinių norui aktyviau dalyvauti

1 lentelè. Mokinių charakteristika ( $\mathrm{n}=3574)$

Pastaba.18,5 proc. (660) mokiniu nežinojo, koks yra ju mamos išsilavinimas, 26,3 proc. (939) teige nežinantys, koks yra jų téčio išsilavinimas, 1,2 proc. (43) mokiniu neatsakè, kokia yra jų mokymosi mokykloje trukmè bei 7,9 proc. (284) mokiniu nenurodè, koks yra ju pastarojo pusmečio pažymiu vidurkis.

\begin{tabular}{|c|c|c|c|}
\hline \multicolumn{2}{|c|}{ Mokinius charakterizuojantys veiksniai } & \multirow{2}{*}{$\begin{array}{l}\text { proc. } \\
1676\end{array}$} & \multirow{2}{*}{$\frac{\text { n }}{46,9}$} \\
\hline Lytis & Berniukas & & \\
\hline & Mergaitè & 1898 & 53,1 \\
\hline \multirow[t]{2}{*}{ Klasė } & 9 klasė & 1798 & 50,3 \\
\hline & 10 klasè & 1776 & 49,7 \\
\hline \multirow[t]{3}{*}{ Amžius } & 14,15 metų & 1256 & 35,1 \\
\hline & 16 metų & 1712 & 47,9 \\
\hline & 17,18 metur & 606 & 17,0 \\
\hline \multirow[t]{3}{*}{ Gyvenamoji vieta } & Kaimas & 1239 & 34,7 \\
\hline & Miestelis & 745 & 20,8 \\
\hline & Miestas & 1590 & 44,5 \\
\hline \multirow[t]{3}{*}{ Mamos išsilavinimas } & Pagrindinis, vidurinis & 842 & 28,9 \\
\hline & $\begin{array}{l}\text { Specialusis vidurinis, aukštesnysis, } \\
\text { profesinis }\end{array}$ & 1073 & 36,8 \\
\hline & Aukštasis & 999 & 34,3 \\
\hline \multirow[t]{3}{*}{ Tėčio išsilavinimas } & Pagrindinis, vidurinis & 759 & 28,8 \\
\hline & $\begin{array}{l}\text { Specialusis vidurinis, aukštesnysis, } \\
\text { profesinis }\end{array}$ & 1275 & 48,4 \\
\hline & Aukštasis & 601 & 22,8 \\
\hline \multirow{3}{*}{$\begin{array}{l}\text { Mokymosi moky- } \\
\text { kloje trukmé }\end{array}$} & 2 metai ir trumpiau & 1630 & 46,3 \\
\hline & Nuo 2 metų iki 9 metų & 684 & 19,4 \\
\hline & 9 metai ir ilgiau & 1217 & 34,5 \\
\hline \multirow{3}{*}{$\begin{array}{l}\text { Pastarojo pusmečio } \\
\text { pažymių vidurkis }\end{array}$} & 5 balai ir mažiau & 260 & 7,9 \\
\hline & Nuo 6 iki 8 balu & 2068 & 62,9 \\
\hline & 9 balai ir daugiau & 962 & 29,2 \\
\hline \multirow[t]{2}{*}{ Mokyklos tipas } & Pagrindinè & 1035 & 29,0 \\
\hline & Gimnazija & 2539 & 71,0 \\
\hline \multirow[t]{2}{*}{ Mokyklos vieta } & Kaimas, miestelis & 1645 & 46,1 \\
\hline & Miestas, didysis miestas & 1928 & 53,9 \\
\hline \multirow{2}{*}{$\begin{array}{l}\text { Mokyklos priklausy- } \\
\text { mas SSM tinklui }\end{array}$} & Mokykla priklauso SSM tinklui & 1327 & 37,1 \\
\hline & Mokykla nepriklauso SSM tinklui & 2247 & 62,9 \\
\hline
\end{tabular}


mokykloje vykdomame jų sveikatos stiprinimo procese, buvo regresijos diagnostiką. Iš logistinès regresijos modelio gauti sudarytas logistinès regresijos modelis ir ịvertinas atlikus pakoreguoti šansų santykiai (ŠS (p), apskaičiuoti jų 95 proc.

2 lentelè. Mokinių dalyvavimo sveikatos stiprinimo procese dažnis ( $\mathrm{n}=3574)$

* Mann Whitney testas; ** Kruskal Wallis testas

\begin{tabular}{|c|c|c|c|c|c|c|}
\hline \multirow{3}{*}{$\begin{array}{l}\text { Mokinius charakterizuojan- } \\
\text { tys veiksniai }\end{array}$} & \multicolumn{6}{|c|}{ Dalyvavimo aktyvumas, proc. (abs. sk.) } \\
\hline & $\begin{array}{c}\text { Nedalyvau- } \\
\text { jantys } \\
(0-3 \text { balai })\end{array}$ & $\begin{array}{c}\text { Pasyvūs } \\
\text { dalyviai } \\
(4-7 \text { balai) }\end{array}$ & $\begin{array}{c}\text { Vidutiniškai } \\
\text { aktyvūs } \\
(8-11 \text { balų) }\end{array}$ & $\begin{array}{c}\text { Aktyvūs } \\
\text { dalyviai } \\
(12-15 \text { balų })\end{array}$ & $\begin{array}{c}\text { Labai aktyvūs } \\
\text { dalyviai } \\
(16-20 \text { balų })\end{array}$ & \multirow[t]{2}{*}{$\underset{\text { reikšmė }}{\mathbf{p}}$} \\
\hline & $48,1(1718)$ & $27,6(985)$ & $14,3(510)$ & $7,4(264)$ & $2,7(97)$ & \\
\hline \multicolumn{7}{|l|}{ Lytis } \\
\hline Berniukas & $53,5(897)$ & $24,8(416)$ & $12,0(201)$ & $7,2(121)$ & $2,4(41)$ & \multirow[t]{2}{*}{$<0,0001 *$} \\
\hline Mergaitė & $43,3(821)$ & $30,0(569)$ & $16,3(309)$ & $7,5(143)$ & $3,0(56)$ & \\
\hline \multicolumn{7}{|l|}{ Klasė } \\
\hline 9 klasė & $47,9(856)$ & $29,8(536)$ & $13,1(236)$ & $6,7(120)$ & $2,4(44)$ & \multirow[t]{2}{*}{$0,248^{*}$} \\
\hline 10 klasė & $48,2(856)$ & $25,3(449)$ & $15,4(274)$ & $8,1(144)$ & $3,0(53)$ & \\
\hline \multicolumn{7}{|l|}{ Amžius } \\
\hline 14,15 metu & $47,9(601)$ & $30,4(382)$ & $12,7(160)$ & $6,0(75)$ & $3,0(38)$ & \multirow{3}{*}{$0,001 * *$} \\
\hline 16 metu & $50,2(860)$ & $25,3(433)$ & $14,8(254)$ & $7,6(130)$ & $2,0(35)$ & \\
\hline 17,18 metų & $42,4(257)$ & $28,1(170)$ & $15,8(96)$ & $9,7(59)$ & $2,0(24)$ & \\
\hline \multicolumn{7}{|l|}{ Gyvenamoji vieta } \\
\hline Kaimas & $44,7(554)$ & $28,8(357)$ & $15,8(196)$ & $7,5(93)$ & $3,1(39)$ & \multirow{3}{*}{$<0,0001 * *$} \\
\hline Miestelis & $42,3(315)$ & $30,5(227)$ & $14,4(107)$ & $10,2(76)$ & $2,7(20)$ & \\
\hline Miestas & $53,4(849)$ & $25,2(401)$ & $13,0(207)$ & $6,0(95)$ & $2,4(38)$ & \\
\hline \multicolumn{7}{|l|}{ Mamos išsilavinimas } \\
\hline Pagrindinis, vidurinis & $44,9(378)$ & $28,1(237)$ & $15,3(129)$ & $8,2(69)$ & $3,4(29)$ & \multirow{3}{*}{$0,300 * *$} \\
\hline $\begin{array}{l}\text { Specialusis vidurinis, aukštes- } \\
\text { nysis, profesinis }\end{array}$ & $43,7(469)$ & $29,4(315)$ & $15,7(168)$ & $8,7(93)$ & $2,6(28)$ & \\
\hline Aukštasis & $46,7(467)$ & $28,5(285)$ & $14,8(148)$ & $7,3(73)$ & $2,6(26)$ & \\
\hline \multicolumn{7}{|l|}{ Téčio išsilavinimas } \\
\hline Pagrindinis, vidurinis & $43,5(330)$ & $27,9(212)$ & $15,4(117)$ & $9,4(71)$ & $3,8(29)$ & \multirow{3}{*}{$0,125^{* *}$} \\
\hline $\begin{array}{l}\text { Specialusis vidurinis, aukštes- } \\
\text { nysis, profesinis }\end{array}$ & $44,9(573)$ & $29,0(370)$ & $14,9(190)$ & $8,5(109)$ & $2,6(33)$ & \\
\hline Aukštasis & $47,3(284)$ & $29,0(174)$ & $15,0(90)$ & $6,2(37)$ & $2,7(16)$ & \\
\hline \multicolumn{7}{|l|}{ Mokymosi mokykloje trukmè } \\
\hline 2 metai ir trumpiau & $51,3(836)$ & $27,7(452)$ & $12,8(208)$ & $6,3(103)$ & $1,9(31)$ & \multirow{3}{*}{$<0,0001 * *$} \\
\hline Nuo 2 metų iki 9 metų & $47,8(327)$ & $26,8(183)$ & $15,4(105)$ & $7,7(53)$ & $2,3(16)$ & \\
\hline 9 metai ir ilgiau & $44,0(535)$ & $28,2(343)$ & $15,3(186)$ & $8,5(103)$ & $4,1(50)$ & \\
\hline \multicolumn{7}{|c|}{ Pastarojo pusmečio pažymių vidurkis } \\
\hline 5 balai ir $<$ & $53,5(139)$ & $20,0(52)$ & $18,1(47)$ & $5,4(14)$ & $3,1(8)$ & \multirow{3}{*}{$<0,0001 * *$} \\
\hline Nuo 6 iki 8 balų & $49,5(1023)$ & $28,3(586)$ & $12,9(267)$ & $7,1(147)$ & $2,2(45)$ & \\
\hline 9 balai ir $>$ & $41,5(399)$ & $29,8(287)$ & $16,3(157)$ & $8,5(82)$ & $3,8(37)$ & \\
\hline \multicolumn{7}{|l|}{ Mokyklos tipas } \\
\hline Pagrindinė & $44,8(464)$ & $27,1(280)$ & $15,4(159)$ & $9,4(97)$ & $3,4(35)$ & \multirow[t]{2}{*}{ 0,001* } \\
\hline Gimnazija & $49,4(1254)$ & $27,8(705)$ & $13,8(351)$ & $6,6(167)$ & $2,4(62)$ & \\
\hline \multicolumn{7}{|l|}{ Mokyklos vieta } \\
\hline Kaimas, miestelis & $42,8(704)$ & $28,8(474)$ & $16,4(270)$ & $8,5(140)$ & $3,5(58)$ & \multirow{2}{*}{$<0,0001 *$} \\
\hline Miestas, didysis miestas & $52,6(1014)$ & $26,5(511)$ & $12,4(240)$ & $6,4(124)$ & $2,0(39)$ & \\
\hline \multicolumn{7}{|c|}{ Mokyklos priklausymas SSM tinklui } \\
\hline Priklauso & $45,2(600)$ & $28,3(376)$ & $14,7(195)$ & $8,9(118)$ & $2,9(38)$ & \multirow[t]{2}{*}{$<0,0001 *$} \\
\hline Nepriklauso & $49,8(1118)$ & $21,7(609)$ & $14,0(315)$ & $6,5(146)$ & $2,6(59)$ & \\
\hline
\end{tabular}


PI. Skirtumas laikomas statistiškai reikšmingu kai $\mathrm{p} \leq 0,05$.

\section{Tyrimo rezultatai ir jų apta- rimas}

Respondentų charakteristika. Tyrimo metu buvo apklausti 3574 mokiniai, iš kurių 53,1 proc. sudarè mergaitès ir 46,9 proc. berniukai. Pagal klasę, kurioje mokosi, mokiniai pasiskirste panašiai. Mokiniu amžiaus vidurkis buvo $15,8( \pm 0,8)$. Beveik puse apklaustų mokinių buvo 16 metų (47,9 proc.), gyveno mieste $(44,5$ proc.), mokykloje mokèsi 2 metus ir trumpiau (46,3 proc.). Vertinant mokiniu pasiskirstymą pagal jų tévų išsilavinimą, nustatyta, kad daugiausiai mokinių tèvų buvo igiję specialųji vidurini, aukštesnijji arba profesini išsilavinimą (atitinkamai 36,8 proc. mamy ir 48,4 proc. tèčių). Daugiau nei pusè respondentų mokèsi gimnazijose (71,0 proc.), miestuose ir didžiuosiuose miestuose esančiose mokyklose (53,9 proc.), ugdymo įstaigose, nepriklausančiose SSM tinklui (62,9 proc.) bei teigè, kad jų pastarojo pusmečio pažymių vidurkis buvo nuo 6 iki 8 balų $(62,9$ proc.) (1 lentelè).

Mokinių dalyvavimo jų sveikatos stiprinimo procese aktyvumas. Kas dešimtas mokinys (9,9 proc., 95 proc. PI: 9,0; 10,9) teigè, kad nuolat dalyvauja mokykloje vykdomame jų sveikatos stiprinimo procese, o daugiau nei pusè respondentų ( 54,7 proc., 95 proc. PI: 53,1; 56,4) nurodè, kad minètame procese dalyvavo pastarujų metų laikotarpiu. Analizuojant mokinių aktyvumo rezultatus buvo nustatyta, kad aktyviai arba labai aktyviai šiame procese dalyvavo tik 10,1 proc. mokinių. Pabrěžtina, kad nedalyvaujantys arba mokiniu sveikatos stiprinimo procese pasy- viai dalyvaujantys mokiniai sudarė net 75,7 proc. visų apklaustujų̨. Šie mūsų tyrimo rezultatai panašūs ị 2016 metais atlikto tyrimo rezultatus, kurie parodè, kad beveik 40 proc. mažujų miestų mokyklų ir beveik 30 proc. didžiųjų miestų mokyklų mokinių teigè dalyvavę sveikatos ugdymo ir stiprinimo veikloje [15]. Panašius duomenimis 2012 metais pateike ir A. de Roiste bei bendraautoriai (atlikto tyrimo duomenimis, apie ketvirtadalis mokinių dalyvavo kuriant mokyklos taisykles, beveik 60 proc. mokykloje prisidejo organizuojant renginius) [16].

Vertinant įvairių mokinių grupių dalyvavimo aktyvumą mokykloje vykdomame jų sveikatos stiprinimo procese, nustatyta, kad reikšmingai aktyviau dalyvavo mergaitès nei berniukai. Didesnị mergaičių aktyvumą nustatè ir Airijos mokslininkai: tarp mergaičių buvo reikšmingai daugiau paauglių, dalyvavusių organizuojant renginius, nei tarp berniuku [16]. Mokiniu aktyvumas dalyvaujant mokykloje vykdomame sveikatos stiprinimo procese buvo susijęs ir su mokyklos veiksniais: reikšmingai aktyvesni buvo kaimų ir miestelių mokyklų mokiniai, palyginus su miestų ir didžiųjų miestų mokyklų mokiniais. Mūsų nuomone, tokius tyrimo rezultatus galejo lemti tai, kad kaimuose ir miesteliuose esančiose mokyklose mokosi mažiau mokinių, neretai šios mokyklos būna vienintelès ugdymo įstaigos toje vietovèje, tad tikètina, kad tokių mokyklų bendruomenès narius sieja artimesni ir stipresni ryšiai, todèl mokiniai aktyviau dalyvauja mokykloje vykdomame jų sveikatos stiprinimo procese. Būtina pabrež̌ti, kad SSM mokiniai reikšmingai aktyviau dalyvavo mokykloje vykdomame sveikatos stiprinimo procese, nei mokyklų, nepriklausančių SSM tinklui, mokiniai. Tokie rezultatai rodo, kad SSM vykdoma veikla yra efektyvi ir duoda teigiamų rezultatų. Tyrimo rezultatai atskleidè, kad reikšmingai aktyvesni buvo aukščiausiais balais besimokantys mokiniai, palyginus su žemiausiais balais besimokančiais mokiniais,

3 lentelẻ. Veiklos, ị kurias ịsitraukia mokiniai, dalyvaudami sveikatos stiprinimo procese $(\mathrm{n}=3574)$

\begin{tabular}{|c|c|c|c|}
\hline \multirow{2}{*}{$\begin{array}{l}\text { Veiklos, i kurias ịsitraukia mo- } \\
\text { kiniai, dalyvaudami mokykloje } \\
\text { vykdomame jų sveikatos stipri- } \\
\text { nimo procese }\end{array}$} & \multicolumn{3}{|c|}{ Dalyvavimas, proc. (95 proc. PI), (abs. sk.) } \\
\hline & \begin{tabular}{|c|} 
taip, \\
per pastaruosius \\
metus
\end{tabular} & $\begin{array}{c}\text { taip, } \\
\text { daugiau nei } \\
\text { prieš metus }\end{array}$ & $\begin{array}{c}\text { ne, } \\
\text { niekada }\end{array}$ \\
\hline Dalyvavimas renginiuose & $\begin{array}{c}41,9(40,3 ; 43,51) \\
(1497)\end{array}$ & $\begin{array}{c}25,5(24,1 ; 26,9) \\
(910)\end{array}$ & $\begin{array}{c}32,7(31,1 ; 34,2) \\
(1167)\end{array}$ \\
\hline Pagalba organizuojant renginius & $\begin{array}{c}21,8(20,5 ; 23,2) \\
(779)\end{array}$ & $\begin{array}{c}24,1(22,7 ; 25,5) \\
(860)\end{array}$ & $\begin{array}{c}54,1(52,5 ; 55,8) \\
(1935)\end{array}$ \\
\hline $\begin{array}{l}\text { Renginiams reikalingų priemoniu } \\
\text { gamyba }\end{array}$ & $\begin{array}{c}19,7(18,4 ; 21,0) \\
(703)\end{array}$ & $\begin{array}{c}21,3(20,1 ; 22,7) \\
(762)\end{array}$ & $\begin{array}{c}59,0(57,4 ; 60,6) \\
(2109)\end{array}$ \\
\hline $\begin{array}{l}\text { Prisidèjimas rengiant mokyklos } \\
\text { sveikatos programą }\end{array}$ & $\begin{array}{c}13,3(12,2 ; 14,4) \\
(475)\end{array}$ & $\begin{array}{c}15,9(14,8 ; 17,2) \\
(569)\end{array}$ & $\begin{array}{c}70,8(69,3 ; 72,3) \\
(2530)\end{array}$ \\
\hline Renginių vedinimas & $\begin{array}{c}12,1(11,1 ; 13,2) \\
(432)\end{array}$ & $\begin{array}{c}13,9(12,8 ; 15,1) \\
(498)\end{array}$ & $\begin{array}{c}74,0(72,5 ; 75,4) \\
(2644)\end{array}$ \\
\hline $\begin{array}{l}\text { Sveikatos stiprinimo veiklos ver- } \\
\text { tinimas }\end{array}$ & $\begin{array}{c}11,0(10,0 ; 12,0) \\
(391)\end{array}$ & $\begin{array}{c}18,0(16,8 ; 19,3) \\
(643)\end{array}$ & $\begin{array}{c}71,0(69,5 ; 72,5) \\
(2539)\end{array}$ \\
\hline $\begin{array}{l}\text { Sveikatos stiprinimo temų siūly- } \\
\text { mas }\end{array}$ & $\begin{array}{c}10,7(9,7 ; 11,7) \\
(381) \\
\end{array}$ & $\begin{array}{c}18,2(17,0 ; 19,5) \\
(650)\end{array}$ & $\begin{array}{c}71,2(69,7 ; 72,6) \\
(2543) \\
\end{array}$ \\
\hline $\begin{array}{l}\text { Sveikatos stiprinimo veiklos ver- } \\
\text { tinimo aptarimas }\end{array}$ & $\begin{array}{c}8,9(8,0 ; 9,9) \\
(317) \\
\end{array}$ & $\begin{array}{c}14,6(13,5 ; 15,8) \\
(521)\end{array}$ & $\begin{array}{c}76,6(75,1 ; 77,9) \\
(2736) \\
\end{array}$ \\
\hline $\begin{array}{l}\text { Sveikatos stiprinimo priemonių } \\
\text { siūlymas }\end{array}$ & $\begin{array}{c}7,2(6,4 ; 8,1) \\
(256)\end{array}$ & $\begin{array}{c}15,3(14,1 ; 16,5) \\
(546)\end{array}$ & $\begin{array}{c}77,6(76,2 ; 78,9) \\
(2772) \\
\end{array}$ \\
\hline Finansinės paramos paieška & $\begin{array}{c}5,2(4,5 ; 6,0) \\
(185)\end{array}$ & $\begin{array}{c}7,2(6,4 ; 8,1) \\
(259)\end{array}$ & $\begin{array}{c}87,6(86,5 ; 88,6) \\
(3130)\end{array}$ \\
\hline
\end{tabular}


bei ilgiausiai mokyklą, kurioje vykdyta apklausa, lankantys mokiniai, palyginus su apklaustaisiais, kurie mokykloje mokèsi trumpiau nei 9 metus (2 lentelè).

Veiklos, ị kurias įsitraukia mokiniai, dalyvaudami mokykloje vykdomame jų sveikatos stiprinimo procese. Vertinant veiklas, $i$ kurias įsitraukia mokiniai, dalyvaudami mokykloje vykdomame jų sveikatos stiprinimo procese, nustatyta, kad daugiausia respondentų dalyvavo renginiuose (41,9 proc. per pastaruosius metus) bei padejo juos organizuoti (21,8 proc. per pastaruosius metus). Kas penktas respondentas (19,7 proc.) per pastaruosius metus gamino renginiams reikalingas priemones. Tyrimo rezultatai atskleidè, kad mažiausiai mokinių siūlè sveikatos stiprinimo priemones (7,2 proc. per pastaruosius metus) bei ieškojo reikalingos finansinès paramos ( 5,2 proc. per pastaruosius metus) (3 lentelè). Dideli sveikatos stiprinimo renginių, kuriuose dalyvauja mokiniai, paplitimą mokyklose patvirtino dar $2007 \mathrm{~m}$. atliktas tyrimas, kurio duomenimis, net 96 proc. mokyklų vadovų teigè, kad jų vadovaujamose mokyklose organizuojami sveikatinimo renginiai [17]. Tai, kad pakankamai didelè dalis mokinių dalis dalyvauja ịvairiuose renginiuose, atskleide ir R. Raškevičienès ir bendraautorių atliktas tyrimas, kurio duomenimis, daugiau nei puse 14-17 metų paauglių dalyvavo su sveikatingumu susijusiose programose, renginiuose apie mitybos sutrikimus, ịvairiose varžybose [18].

4 lentelè. Veiksniai, darantys įtaką mokinių norui aktyviau dalyvauti sveikatos stiprinimo procese

$N=3290$. Modelio tikétinumo santykio $\chi^{2}=65,64 ;$ lls $8 ; p<0,0001$; Hosmer ir Lemeshow $\chi^{2}=7,28$; lls $8 ; p=0,507 ;$ R2 0,019.

\begin{tabular}{|c|c|c|c|c|}
\hline $\begin{array}{l}\text { Mokinius charakte- } \\
\text { rizuojantys } \\
\text { veiksniai }\end{array}$ & ŠS (b) & $\overline{\text { ŠS (p) }}$ & $\begin{array}{c}95 \text { proc. } \\
\text { PI }\end{array}$ & p reikšmè \\
\hline $\begin{array}{l}\text { Lytis } \\
\text { Berniukas } \\
\text { Mergaite }\end{array}$ & $\begin{array}{l}1,00 \\
1,82\end{array}$ & 1,81 & 1,$51 ; 2,16$ & $<0,0001$ \\
\hline $\begin{array}{l}\text { Amžius } \\
17,18 \text { metų } \\
16 \text { metų } \\
14,15 \text { metų }\end{array}$ & $\begin{array}{l}1,00 \\
1,26 \\
1,36\end{array}$ & $\begin{array}{l}1,18 \\
1,27\end{array}$ & $\begin{array}{l}0,92 ; 1,52 \\
0,98 ; 1,64\end{array}$ & $\begin{array}{l}0,184 \\
0,071\end{array}$ \\
\hline $\begin{array}{l}\text { Gyvenamoji vieta } \\
\text { Miestas } \\
\text { Miestelis } \\
\text { Kaimas }\end{array}$ & $\begin{array}{l}1,00 \\
1,25 \\
1,07\end{array}$ & $\begin{array}{l}1,24 \\
1,14\end{array}$ & $\begin{array}{l}0,99 ; 1,55 \\
0,94 ; 1,39\end{array}$ & $\begin{array}{l}0,051 \\
0,172\end{array}$ \\
\hline $\begin{array}{l}\text { Pažymių vidurkis } \\
5 \text { balai ir mažiau } \\
\text { Nuo } 6 \text { iki } 8 \text { balų } \\
9 \text { balai ir daugiau }\end{array}$ & $\begin{array}{l}1,00 \\
1,41 \\
1,75\end{array}$ & $\begin{array}{l}1,21 \\
1,36\end{array}$ & $\begin{array}{l}0,84 ; 1,72 \\
0,94 ; 1,99\end{array}$ & $\begin{array}{l}0,305 \\
0,107\end{array}$ \\
\hline $\begin{array}{l}\text { Mokyklos priklau- } \\
\text { symas SSM tinklui } \\
\text { Nepriklauso } \\
\text { Priklauso }\end{array}$ & $\begin{array}{l}1,00 \\
1,07\end{array}$ & 1,12 & 0,$94 ; 1,33$ & 0,207 \\
\hline
\end{tabular}

Mokinių noras aktyviau dalyvauti mokykloje vykdomame jų sveikatos stiprinimo procese. Nustatyta, kad mokykloje vykdomame mokinių sveikatos stiprinimo procese aktyviau dalyvauti norejo tik kas penktas mokinys $(21,1$ proc., 95 proc. PI: 19,2; 22,5), beveik pusè respondentų $(48,8$ proc., 95 proc. PI: 47,$2 ; 50,4)$ aktyviau dalyvauti norejo tik iš dalies, likusieji mokiniai ( 30,1 proc., 95 proc. PI: 26,8 ; $31,6)$ aktyviau dalyvauti nenorejo. Analizuojant veiksnius, darančius įtaką mokinių norui aktyviau dalyvauti mokykloje vykdomame jų sveikatos stiprinimo procese, nustatyta, kad reikšmingą įtaką darè tik lytis: mergaitès turèjo 1,81 karto reikšmingai didesnį šansą norèti aktyviau dalyvauti sveikatos stiprinimo procese nei berniukai (4 lentelè).

Mokinių dalyvavimo mokykloje vykdomame sveikatos stiprinimo procese lūkesčiai bei aktyvesniam dalyvavimui trukdančios priežastys. Tyrimas atskleide, kad nemažos mokinių dalies dalyvavimo jų sveikatos stiprinimo procese lūkesčiai buvo pozityvūs: daugiau nei pusè respondentų $(53,1$ proc.) teigè, kad dalyvaudami mokykloje vykdomame sveikatos stiprinimo procese jie igis sveikatos stiprinimui reikalingų žinių, 41,0 proc. apklaustųų nurodè, kad dèl da-

5 lentelè. Mokinių dalyvavimo sveikatos stiprinimo procese lūkesčiai $(n=3574)$

\begin{tabular}{|l|c|c|c|}
\hline Mokinių dalyvavimo lūkesčiai & proc. & 95 proc. PI & n \\
\hline $\begin{array}{l}\text { Aš igysiu sveikatos stiprinimui rei- } \\
\text { kalingų žinių }\end{array}$ & 53,1 & 51,$4 ; 54,7$ & 1897 \\
\hline Aš tapsiu fiziškai aktyvesnis & 41,0 & 39,$4 ; 42,6$ & 1466 \\
\hline $\begin{array}{l}\text { Mano mityba taps sveikatai palan- } \\
\text { kesnė }\end{array}$ & 38,8 & 37,$2 ; 40,4$ & 1387 \\
\hline Pagerės mano sveikata & 38,1 & 36,$6 ; 39,7$ & 1363 \\
\hline $\begin{array}{l}\text { Mano dalyvavimas neturès jokios } \\
\text { itakos }\end{array}$ & 16,4 & 15,$2 ; 17,6$ & 585 \\
\hline Aš atsisakysiu žalingų ịpročių & 13,5 & 12,$4 ; 14,7$ & 483 \\
\hline
\end{tabular}

6 lentelè. Priežastys, trukdančios mokiniams aktyviau dalyvauti sveikatos stiprinimo procese $(\mathrm{n}=3574)$

\begin{tabular}{|l|c|c|c|}
\hline Priežastys & proc. & $\mathbf{9 5}$ proc. PI & n \\
\hline Mano laiko stoka & 60,8 & 59,$2 ; 62,4$ & 2172 \\
\hline Mano noro stoka & 52,5 & 50,$8 ; 54,1$ & 1875 \\
\hline Mano žinių stoka & 24,3 & 22,$9 ; 25,7$ & 868 \\
\hline $\begin{array}{l}\text { Neatsižvelgimas ị mokinių nuo- } \\
\text { monę }\end{array}$ & 17,9 & 16,$7 ; 19,2$ & 639 \\
\hline Mokytojų iniciatyvos ir noro stoka & 17,0 & 15,$8 ; 18,3$ & 607 \\
\hline $\begin{array}{l}\text { Kitų mokyklos darbuotojų iniciaty- } \\
\text { vos ir noro stoka }\end{array}$ & 13,6 & 12,$5 ; 14,7$ & 485 \\
\hline $\begin{array}{l}\text { Mokyklos vadovo iniciatyvos ir } \\
\text { noro stoka }\end{array}$ & 11,6 & 10,$6 ; 12,7$ & 414 \\
\hline $\begin{array}{l}\text { Aš aktyviai dalyvauju, man ne- } \\
\text { trukdo jokios priežastys }\end{array}$ & 5,1 & 4,$4 ; 5,8$ & 181 \\
\hline
\end{tabular}


lyvavimo taps fiziškai aktyvesni, nemažai mokinių $(38,1$ proc.) manè, kad pagerés jų sveikata. Vis dèlto 16,4 proc. mokinių buvo ịsitikinę, kad jų dalyvavimas šiame procese neturès jokios įtakos. Kiti mokinių dalyvavimo jų sveikatos stiprinimo procese lūkesčiai pateikti 5 lentelèje.

Didžiausia dalis mokiniu ( 60,8 proc.) teigè, kad jiems aktyviau dalyvauti mokykloje vykdomame jų sveikatos stiprinimo procese trukdo laiko stoka, daugiau nei pusè respondentų (52,5 proc.) nurodè, kad jiems trukdo noro stoka, beveik kas ketvirtas mokinys $(24,4$ proc.) kaip vieną iš pagrindinių aktyviau dalyvauti sveikatos stiprinimo procese trukdančių priežasčių îvardijo žinių stoką. Panašias mokyklos bendruomenès narių nedalyvavimo mokykloje vykdomame mokinių sveikatos stiprinimo procese priežastis (žinių, laiko ir entuziazmo stoką) įvardijo ir J. Jafarov bei kiti mokslininkai $[19,20]$.

Tyrimo rezultatai parodè, kad mažiausiai mokinių teigè, jog jiems aktyviau dalyvauti mokykloje vykdomame jų sveikatos stiprinimo procese trukdè kitų mokyklos darbuotojų ir mokyklos vadovo iniciatyvos ir noro stoka (atitinkamai13,6 proc. ir 11,6 proc.). Pabrèžtina, kad tik 5,1 proc. mokinių nurodè, kad mokykloje vykdomame mokinių sveikatos stiprinimo procese jie aktyviai dalyvauja ir jiems netrukdo jokios priežastys (6 lentelè).

\section{Išvados}

1. Mokykloje vykdomame mokinių sveikatos stiprinimo procese aktyviai ar labai aktyviai dalyvavo tik kas dešimtas mokinys. Didžioji dalis mokinių sveikatos stiprinimo procese nedalyvavo arba buvo pasyvūs dalyviai.

2. Mokinių aktyvumas buvo reikšmingai susijęs su jų lytimi, amžiumi, gyvenamaja vieta, mokymosi mokykloje trukme, pastarojo pusmečio pažymių vidurkiu, mokyklos tipu, jos vieta bei ugdymo ịstaigos priklausymu (nepriklausymu) SSM tinklui.

3. Didžiausia dalis mokinių, dalyvaudami mokykloje vykdomame jų sveikatos stiprinimo procese, dalyvavo renginiuose bei padejo juos organizuoti, mažiausia dalis - siūlè sveikatos stiprinimo priemones ir ieškojo finansinès paramos.

4. Beveik 70 proc. mokinių norejo arba bent iš dalies norejo aktyviau dalyvauti mokykloje vykdomame jų sveikatos stiprinimo procese. Mergaitės turèjo reikšmingai didesni šansą norèti dalyvauti minètame procese nei berniukai. Kiti veiksniai reikšmingos įtakos tokiam respondentų norui nedarè.

5. Daugiausia respondentų teigè, kad dalyvaudami sveikatos stiprinimo procese, jie igis sveikatos stiprinimui reikalingų žinių bei taps fiziškai aktyvesni. Mažiausiai respondentų buvo įsitikinę, kad jų dalyvavimas neturès jokios įtakos bei kad jie atsisakys žalingų ịpročių.
6. Didžiausiai daliai mokinių aktyviau dalyvauti mokykloje vykdomame jų sveikatos stiprinimo procese trukdè laiko, noro bei žinių stoka, mažiausiai daliai respondentų trukdė mokyklos vadovo bei kitų mokyklos darbuotojų iniciatyvos ir noro stoka. Vos 5 proc. mokinių teige, kad jie aktyviai dalyvauja mokykloje vykdomame jų sveikatos stiprinimo procese ir jiems netrukdo jokios priežastys.

\section{Literatūra}

1. Issanchou S. Determining factors and critical periods in the formation of eating habits: results from the Habeat project. Ann Nutr Metab 2017;70(3):251-6.

https://doi.org/10.1159/000471514

2. World Health Organization. First international conference on health promotion. Ottawa, 21 November 1986.

https://www.who.int/teams/health-promotion/enhancedwellbeing/first-global-conference

3. Savina E, Garrity K, Kenny P, Doerr C. The benefits of movement for youth: a whole child approach. Contemp School Psychol 2016;20(3):282-92.

https://doi.org/10.1007/s40688-016-0084-z

4. Schools for Health in Europe Network Foundation (SHE). School health promotion: evidence for effective action. 4th European Conference on Health Promoting Schools. Denmark: SHE 2013. https://www.schoolsforhealth.org/sites/default/files/ editor/fact-sheets/she-factsheet-2-school-health-promotionevidence.pdf

5. Lietuvos Respublikos švietimo įstatymas. Aktuali redakcija 2020-11-10. https://e-seimas.lrs.lt/portal/legalAct/lt/TAD/ TAIS. 1480/asr

6. World Health Organization. Health Promotion Glossary. Geneva: WHO 1998. https://www.who.int/healthpromotion/about/ HPR\%20Glossary\%201998.pdf

7. John-Akinola YO, Nic-Gabhainn S. Children's participation in school: a cross-sectional study of the relationship between school environments, participation and health and well-being outcomes. BMC Public Health 2014;14(1).

https://doi.org/10.1186/1471-2458-14-964

8. Cheng ECK, Leung YW, Yuen WW, Tang HHH. A model for promoting student participation in school governance. IJEM 2019;34(4):737-49.

https://doi.org/10.1108/IJEM-06-2019-0186

9. Simovska V, Bruun Jensen B. Conceptualizing participation: the health of children and young people. WHO, Regional Office for Europe 2009:32. https://pure.au.dk/portal/en/publications/ conceptualizing-participation(ab53ac70-6fa8-11de-9e37000ea68e967b).html.

10. Griebler U, Rojatz D, Simovska V, Forster R. Effects of student participation in school health promotion: a systematic review. Health Promotion International 2014;32(2):195-206. https:// doi.org/10.1093/heapro/dat090 
11. Valstybinis aplinkos sveikatos centras. Sveikatą stiprinančių mokyklų veiklos vertinimo praktinis vadovas. Vilnius: VASC, 2009. http://www.smlpc.lt/media/file/Skyriu_info/Vaiku_sveikata/SSM/Publikacijos_leidiniai/Veikslos_vertinimo_praktinis_vadovas.pdf.

12. Žukauskienè R. Raidos psichologija. Vilnius: Margi raštai, 2007:297-326.

13. Valius L., Jaruševičienė L. Paauglių sveikatos priežiūra šeimos gydytojo praktikoje. Kaunas: Vitae Litera, 2008:5-17.

14. Patton GC, Sawyer SM, Santelli JS, Ross DA, Afifi R, Allen NB, et al. Our future: a Lancet commission on adolescent health and wellbeing. The Lancet 2016;387(10036):2423-78. https://doi.org/10.1016/S0140-6736(16)00579-1

15. Maceinaitė R. Lietuvos mokyklų bendruomenių dalyvavimas mokinių sveikatą stiprinančiame procese. Master's thesis. Vilnius: Vilniaus universitetas, 2016. https://epublications.vu.lt/ object/elaba:20255247/index.html.

16. de Róiste A, Kelly C, Molcho M, Gavin A, Nic Gabhainn S. Is school participation good for children? Associations with health and wellbeing. Simovska V, editor. Health Education 2012;112(2):88-104.

https://doi.org/10.1108/09654281211203394

17. Gudžinskienė V., Česnavičienė J., Suboč V. Sveikos gyvensenos ugdymas mokyklose. Tyrimo ataskaita. 2007:1-115. https:// www.smm.lt/uploads/documents/kiti/SVEIKOS\%20GYVENSENOS\%20UGDYMAS\%20MOKYKLOSE.pdf.

18. Raškevičienė R., Eičinaitè-Lingienė R., Roženaitė G., Sakalauskas L. 14-17 metų moksleivių požiūris ị savo sveikatą ir sveiką gyvenseną bei sveikatingumo programų poreikis. Visuomenès sveikata. 2016;3(74):32-43. https://www.hi.lt/uploads/pdf/visuomenes\%20sveikata/2016.3(74)/VS\%202016\%203(74)\%20 ORIG\%20Poziuris\%20i\%20sveikata.pdf.

19. Jafarov J. Factors affecting parental involvement in education: the analysis of literature. KJHSS 2015;18(4):35-44. https://doi.org/10.5782/2223-2621.2015.18.4.35

20. O. John-Akinola Y, Nic Gabhainn S. Parental participation in primary schools; the views of parents and children. Health Education 2014;114(5):378-97.

https://doi.org/10.1108/HE-09-2013-0047

\section{PARTICIPATION OF 9TH AND 10TH GRADE STUDENTS IN SCHOOL HEALTH PROMOTION PROCESS}

\section{R. Maceinaitė, G. Šurkienė, R. Sketerskienė, Ž. Žandaras}

Keywords: student's health promotion, participation in health promotion process, school health promotion

Summary

School is considered the most appropriate place for health promotion processes for adolescents. A key component of the health promotion process is participation in it, therefore, for the health promotion process to be effective, it is necessary to involve as many students as possible. The aim of the study - to evaluate the participation of 9th and 10th grade students in school health promotion process. 35749 th and 10th grade students from 110 different Lithuanian schools were interviewed. Prevalence estimates were calculated at 95\% CI, Mann-Whitney U and Kruskal Wallis tests were used for ordinal data analysis. In order to determine the factors influencing the students' willingness to participate more actively in their health promotion process at school, logistic regression models were developed, adjusted odds ratios were obtained and their $95 \%$ CI were calculated. $10.1 \%$ of students were actively or very actively involved in the health promotion process. Their activity was significantly related to gender, age, place of residence, duration of belonging (attending) to school, average grades in the last six months, schools' type, its location and membership in SSM network. In the last year, $41.9 \%$ of students participated in events and $21.8 \%$ of students helped organize events. Nearly 70 percent of students wanted, or at least partially wanted, to be more actively involved in their health promotion process at school, this was significantly related to students' gender. Students had positive expectations about participation in health promotion process: $53.1 \%$ of respondents thought that they would acquire the knowledge for strengthening their health, $41.0 \%$ of students stated that they would become more physically active. Part of the students could not participate more actively in the health promotion process because of their lack of time, willingness and knowledge (respectively $60.8 \%, 52.5 \%$ ir $24.3 \%$ )

Correspondence to: ruta.maceinaite@gmail.com

Gauta 2021-03-05 